Western New England University School of Law Digital Commons @ Western New England University School of Law

2014

\title{
Country Report on Counterterrorism: United States of America
}

Sudha Setty

Western New England University School of Law, ssetty@law.wne.edu

Follow this and additional works at: http:// digitalcommons.law.wne.edu/facschol

Part of the National Security Commons

\section{Recommended Citation}

Sudha Setty, Country Report on Counterterrorism: United States of America, 62 AM. J. COMP. L. 643 (2014).

This Article is brought to you for free and open access by the Faculty Publications at Digital Commons @ Western New England University School of Law. It has been accepted for inclusion in Faculty Scholarship by an authorized administrator of Digital Commons @ Western New England University School of Law. For more information, please contact pnewcombe@law.wne.edu. 


\title{
SUDHA SETTY*
}

\section{Country Report on Counterterrorism: United States of America $\dagger$}

\author{
Topic V. A
}

The terrorist attacks of September 11, 2001 led to profound changes in societal viewpoints, political agendas, and the legal authorization to combat terrorism. The United States continues to struggle with keeping its population safe while maintaining the principles of democracy and the rule of law essential to the nation's character. The U.S. response to terrorism has been multifaceted and expansive, reflective of the U.S. role in global security; debate over these matters will continue for the foreseeable future.

This report offers summary, analysis and critique of many aspects of counterterrorism law, including the definition of terrorism and designation of terrorist organizations; application of international law; criminal law treatment of terrorism, including financing and material support; investigative powers of intelligence and law enforcement agencies; treatment of immigrants; executive power and the CIA targeted killing program; detention and interrogation of terrorism suspects; and access to courts and the treatment of classified information.

\section{INTRODUCTION}

The terrorist attacks of September 11, 2001, which killed almost 3,000 civilians, led to profound changes in societal viewpoints, political agendas, and the legal authority to combat terrorism and threats of terrorism. The United States, like all other democratic nations that have suffered terrorist attacks, continues to struggle with questions of how to keep its population safe while maintaining the principles of democracy and the rule of law that are essential to the nation's character.

* Associate Dean for Faculty Development \& Intellectual Life and Professor of Law, Western New England University School of Law. The author thanks Matthew H. Charity and Lauren Carasik for thoughtful comments and suggestions, and Kelly Heuser for fine research assistance.

$\dagger$ DOI: http://dx.doi.org/10.5131/AJCL.2013.0039 
In the twelve years since the attacks of September 11, Congress, the executive branch and the judicial system have reacted strongly to the need to protect against future national security threats by giving more powers to the police, military, and intelligence forces to investigate potential threats and neutralize them before another attack occurs. Some of the these changes occurred in response to U.N. Security Council resolutions, ${ }^{1}$ but many have been domestically motivated shifts that reflect the will of politicians and the polity as a whole. The expanded powers accorded to these counterterrorism programs have - in the view of many critics-allowed for government infringement on civil liberties and human rights in significant and corrosive ways, with little or no accountability for such overreaching.

In the years immediately following the attacks of September 11, the Bush administration asserted both inherent presidential authority and broad powers conferred under the Authorization for the Use of Military Force ${ }^{2}$ and the USA Patriot Act. ${ }^{3}$ The government conducted warrantless wiretapping surveillance, detained thousands of individuals - almost all of whom were Muslim-who were later released based on lack of evidence of any connection to terrorism, conducted extraordinary renditions to capture and transport suspected individuals from one country to another without judicial oversight, and resorted to torture as an interrogation and control technique on some detainees.

Some of these issues were eventually resolved-through public pressure, judicial intervention and/or a change in political branches-in ways that improved the individual rights of detainees, suspects and the public. Yet robust presidential authority and extremely high levels of secrecy continue to be the norm, and the nation's policymakers still struggle with how best to maintain security, accountability, and the rule of law.

\section{The Definition of Terrorism}

Terrorism is defined in numerous ways under U.S. law, but contains several basic elements: premeditation, political or religious motivation, perpetration of violence, noncombatant targets, and ac-

1. U.N. Security Council Resolution 1373 has played a strong role worldwide in developing a concerted counterterrorism effort. The United States played a significant role in supporting the language and passage of Resolution 1373 and encouraging its worldwide mandate. See Kim Lane Scheppele, Other People's Patriot Acts: Europe's Response to September 11, 50 LoY. L. REV. 89, 91-92 (2004).

2. Authorization for Use of Military Force (AUMF), Pub. L. 107-40, codified at 115 Stat. 224 (Sept. 18, 2001).

3. Uniting and Strengthening America by Providing Appropriate Tools Required to Intercept and Obstruct Terrorism Act of 2001, Pub. L. No. 107-56, 115 Stat. 272 (codified as amended in scattered sections of U.S.C.) [hereinafter Patriot Act]. 
tors as subnational groups or clandestine agents. 4 The United States has not made any exceptions to this definition based on the activity being expressive in character or with regard to national liberation struggles. 5

The USA PATRIOT Act, passed in the weeks immediately following the September 11 attacks, offers both greater counterterrorism resources and more flexibility in implementation to the government, including increased surveillance powers, ${ }^{6}$ increased government authority to conduct intelligence-gathering operations in matters of suspected terrorism, ${ }^{7}$ the power of civil seizure of assets based only on probable cause, ${ }^{8}$ and heightened punishments for any of the underlying crimes related to the newly broadened understanding of "domestic terrorism," which includes:

[A]cts dangerous to human life that are a violation of the criminal laws of the United States or of any State [that] appear to be intended to intimidate or coerce a civilian population; to influence the policy of a government by intimidation or coercion; or to affect the conduct of a government by mass destruction, assassination, or kidnapping; and occur primarily within the territorial jurisdiction of the United States. $^{9}$

This definition of domestic terrorism was the result of intense pressure on Congress ${ }^{10}$ to amend various existing criminal statutes to

4. E.g., 22 U.S.C.A. $§ 2656 \mathrm{f}(2)(\mathrm{d})$ (2) (WEST) (defining terrorism for the purpose of the State Department's annual report to the Speaker of the House and the Senate Committee on Foreign Relations as "premeditated, politically motivated violence perpetrated against noncombatants by subnational groups or clandestine agents"); see Third Mutual Evaluation Report on Anti-Money Laundering And Combating The Financing of Terrorism: United States of America, (Financial Action Task Force, Paris, France) June 2006, at 40, available at http://www.fatf-gafi.org/countries/u-z/united states/documents/mutualevaluationoftheunitedstates.html (offering similar elements of a definition of terrorism for the purposes of evaluation under the Immigration and Nationality Act [Title 8 USC 1182(a)(3)(B)(iv)]).

5. See Sudha Setty, What's in a Name: How Nations Define Terrorism Ten Years After 9/11, 33 U. PA. J. INT'L L. 1 (2011).

6. See Patriot Act $\S 218$ (amending the Foreign Intelligence Surveillance Act of 1978 such that electronic surveillance and physical searches need only be justified in "significant" part by the goal of obtaining foreign intelligence).

7. Patriot Act $\S 901$.

8. Patriot Act $\S 806$.

9. Patriot Act $\S 802$. Critics of this broad definition have noted that such language could encompass numerous activist groups, including Greenpeace, protestors of the World Trade Organization, Operation Rescue, and protesters of bomb-testing facilities on the island of Vieques. See How the USA PATRIOT Act redefines "Domestic Terrorism,” Am. Civ. LiBenties Union (Dec. 6, 2002), http://www.aclu.org/nationalsecurity/how-usa-patriot-act-redefines-domesticterrorism.

10. See Laura K. Donohue, The Cost of Counterterrorism: Power, Politics AND LIBERTY 11 (2008) (arguing that the legislative role in safeguarding civil liberties is hampered by political imperatives). 
broaden and strengthen the government's resources before another attack potentially took place. ${ }^{11}$

The Patriot Act amended the definition of terrorism from 18 U.S.C. $\S 2331$ to broaden its scope and application further, ${ }^{12}$ but included an important sunset provision-added in part because of the haste with which the legislation was passed-that forced Congress to reexamine the legislation at intervals of several years. ${ }^{13}$ Although Congress debated the renewal of certain parts of the Patriot Act in 2005-none of which involved the definition of terrorism-in March 2006, Congress renewed most provisions, removed the safeguard of a sunset provision, and made the provisions permanent. ${ }^{14}$

The current Patriot Act definition of terrorism has a broad scope, and its reach exacerbates the uncertainty surrounding the application of conflicting definitions of terrorism, including the potential lack of notice to individuals as to whether they will be categorized as a terrorist and exactly what kind of conduct is prohibited. ${ }^{15}$

\section{Criminal Laws and Prosecutions}

\section{A. Criminal Law}

Terrorist acts are often prosecuted using the ordinary criminal justice system, particularly when the alleged crime occurred domestically. Statutes such as the Anti-Effective Death Penalty Act of 1996 (AEDPA $)^{16}$ and the Patriot Act were enacted as specific responses to

11. See Robert O'Harrow, Jr., Six Weeks in Autumn, Washington Post MagazINE, Oct. 27, 2002, at 6, 10 (describing the pressured deliberations of Congress and the executive branch in drafting the Patriot Act).

12. See 18 U.S.C. $§ 2331$ (including "mass destruction" as a means by which terrorists operate).

13. See 18 U.S.C. $\$ 2510$ (commenting that Section 801 of Pub. L 90-351 provided a sunset provision for various counterterrorism tools, including those related to wiretapping and surveillance).

14. See James Beckman, Comparative Legal Approaches to Homeland SecurITY AND ANTI-TERRORISM 31 (2007) (describing how sunset provisions were adopted, extended, and then removed). Only three provisions not dealing with the definition of terrorism were still kept subject to the sunset provisions. Id. Those provisions were extended in May 2011 until 2015. See Paul Kane \& Felicia Somnez, Patriot Act Amendments Signed into Law Despite Bipartisan Resistance from Congress, WASHPOST.COM, May 27, 2011, http://www.washingtonpost.com/politics/patriot-act-ex tension-signed-into-law-despite-bipartisan-resistance-incongress/2011/05/27/AGbVls CH_story.html (describing the extension of surveillance provisions of the Patriot Act).

15. See Subcomm. on Terrorism and Homeland Sec. \& House Permanent Select Comm. on Intelligence, 107th Cong., Counterterrorism Capabilities and Performance Prior to 9-11: A Report to the Speaker of the House of RepresentATIVES AND THE MinORITy LEADER (2002), available at http://www.fas.org/irp/congress/ 2002_rpt/hpsci_ths0702.html (reviewing alternative ways to combat terrorism in order to prevent future attacks). The Subcommittee's recommendation that a single definition of terrorism be agreed upon by all U.S. agencies was predicated on a concern that a lack of uniform definition would lead to terrorist acts being treated identically under the law as ordinary criminal acts. Id.

16. Antiterrorism and Effective Death Penalty Act of 1996 (AEDPA), Pub. L. No. 104-132, 110 Stat. 1217 (codified in scatter sections of 8, 18, and 28 U.S.C.). 
terrorist acts and to enable investigation and prosecution of activities that were not previously criminalized.

A serious constitutional issue has been raised with regard to a number of U.S. statutes that criminalize speech-related conduct that supports or encourages violent acts, including terrorist acts. The federal criminal solicitation ${ }^{17}$ and sedition statutes, ${ }^{18}$ for example, authorize such prosecution. However, the most widely used statute in this area criminalizes material support of terrorism. Sections 2339A and 2339B of Title 18 of the U.S. Code prohibit knowingly or intentionally providing, attempting to provide, or conspiring to provide material support or resources to a terrorist organization, defining the term "material support or resources" to include:

any property, tangible or intangible, or service, including currency or monetary instruments or financial securities, financial services, lodging, training, expert advice or assistance, safehouses, false documentation or identification, communications equipment, facilities, weapons, lethal substances, explosives, personnel (1 or more individuals who may be or include oneself), and transportation, except medicine or religious materials. ${ }^{19}$

Material support charges have been used extensively to try terrorism suspects or to exert pressure toward a plea bargain, and are often successful. $^{20}$ Unlike other crimes often invoked to prosecute terror

17. See 18 U.S.C. § 373(a) (criminalizing solicitation of crimes). See also Letter from the Chairman of the Security Council Committee established pursuant to resolution 1373 (2001) concerning counter-terrorism addressed to the President of the Security Council, (June 15, 2006), Enclosure: Response of the United States of America to the Counter-Terrorism Committee: United States implementation of Security Council resolution 1624 (2005), at 5-6, available at http://daccess-dds-ny.un. org / doc / UNDOC/GEN/N06/395/24 / PDF/N0639524.pdf?OpenElement (hereinafter "U.S. CTC Response 2006") (citing the availability of 18 U.S.C. $§ 2332$ (b) (acts of terrorism, such as murder, maiming, or kidnapping, transcending national boundaries), 18 U.S.C. $\S 2332 \mathrm{f}$ (bombings of places of public use), and 49 U.S.C. $§ 46502$ (aircraft piracy) in prosecuting support of terrorism).

18. 18 U.S.C. $\$ 2384$ prohibits seditious conspiracy (plotting to use force to overthrow the government). 18 U.S.C. $\S 2385$ proscribes teaching or advocating the duty or necessity of overthrowing or destroying the government of the United States by force or violence; publishing or circulating literature which so teaches or advocates; joining or organizing any group which so teaches or advocates, knowing the purposes thereof; or conspiring to do any of the foregoing. See U.S. CTC Response 2006, supra note 17 (discussing the availability of these statutes in the counterterrorism context); U.S. v. Rahman, 189 F.3d 88, 116-117 (2nd Cir. 1999) (upholding the solicitation conviction of Sheik Omar Amad Ali Abdel Rahman based on his exhortations for others to bomb New York City facilities and to assassinate certain persons).

19. See 18 U.S.C. $\S \S 2339 A$ and 2339B.

20. See Press Release, Dep't of Justice, Fed. Bureau of Investigation, Minneapolis, Minneapolis Man Sentenced for Conspiracy to Provide Material Support to al Qaeda, (July 9, 2009), http://minneapolis.fbi.gov/dojpressreVpressreI09/mp070909.htm (last visited Oct. 19,2010) (describing the guilty plea of Mohammed Abdullah Warsame to charges of material support for al Qaeda, which resulted in a prison sentence of 
suspects, such as continuing criminal enterprise ${ }^{21}$ and violations of the Racketeer Influenced and Corrupt Organizations Act ${ }^{22}$ which require at least some predicate act for criminal liability to attach, ${ }^{23}$ the material support statute does not require the defendant to have had a specific intent to support a terrorist act; knowing support of a designated terrorist organization without intent is sufficient to convict. ${ }^{24}$ The scope and flexibility offered by the material support statute has made it an often-used tool for prosecutors and was used to convict John Walker Lindh, ${ }^{25}$ Ahmed Omar Abu Ali, ${ }^{26}$ and the so-called "Lackawanna Six,"27 among others.

In 2010, the U.S. Supreme Court decided that the statute does not unconstitutionally infringe on the expressive rights of individuals. ${ }^{28}$ In some respects, this decision promoted additional uncertainty as to what individuals and organizations will be prosecuted under the material support statute, and on what basis. ${ }^{29}$ The United States government maintains, however, that the majority of the terrorist propaganda found on the Internet today could not be prosecuted under U.S. criminal law, and that even a website advocating committing acts of terrorist violence likely lacks (at least without proof of additional facts) the potential to produce imminent lawless action that could be criminalized. ${ }^{30}$

\section{B. Terrorism Prosecutions}

The United States has historically shied away from specialized trials for terrorist attacks, instead relying on the criminal justice sys-

ninety-two months); Philip Coorey, Hicks Case Flawed All Along; Prosecutor, Sydney Morning Herald (Apr. 30, 2008), http://www.smh.com.auJarticlesI2008/04/29/1209 234862811.htrnl (last visited Oct. 19,2010) (detailing David Hicks' guilty plea to material support charges).

21. 21 U.S.C. $\$ 848$ (2008).

22. 18 U.S.C. $\$ \$ 1961-1968$ (2000).

23. See, e.g., 18 U.S.C. $§ 1961(5)$ (2008) (defining racketeering as involving at least two acts in furtherance of the illegal plan).

24. 18 U.S.C. § 2339B(a)(I) (2000).

25. United States v. Lindh, 227 F. Supp. 2d 565 (E.D. Va. 2002) (entering guilty plea in violation of, among other things, the material support statute).

26. United States v. Abu Ali, 528 F.3d 210 (4th Cir. 2008), cert. denied, 129 S. Ct. 1312 (2009).

27. Press Release, U.S. Dep't of Justice, U.S. Attorney, W. Dist. of N.Y., United States Attorney's Office Successfully Concludes Terrorism Case With Sixth Conviction of AI Qaeda Supporter (May 19, 2003) (announcing the conviction of Muhktar alBakri).

28. See Holder v. Humanitarian Law Project, 130 S. Ct. 2705 (2010).

29. See Peter Margulies, Advising Terrorism: Hybrid Scrutiny, Safe Harbors, and Freedom of Speech 63 Hastings L.J. 455, 498 (2011) (arguing that the majority opinion failed to specify how much coordination with a foreign terrorist organization would lead to a violation of the federal statute prohibiting material support to these organizations).

30. U.S. CTC Response 2006, supra note 17, at 4-5. 
tem. ${ }^{31}$ In part, this policy is intended to affirm the rule of law in the United States and to maintain the United States' reputation in the international community for fairness toward criminal defendants ${ }^{32}$ regardless of the crime committed or the national origin or religion of the defendant. ${ }^{33}$

One critique of the criminal justice system with regard to terrorism prosecutions has been the de facto unavailability of the entrapment defense. In evaluating an entrapment defense, most courts will consider whether the defendant was induced into illegal acts by law enforcement or had, to the contrary, a predisposition to commit the crime even if law enforcement had not intervened. In the context of a terrorism prosecution, a defendant's predisposition toward terrorist acts is often inferred from the defendant's political and religious views, or sympathies toward those of the same political bent or religious background who have engaged in terrorist activities. ${ }^{34}$ In the post-9/11 context, there has not been one publicly known instance of a successful entrapment defense in a terrorism case, ${ }^{35}$ despite ample evidence of law enforcement inducing defendants toward illegal activities. ${ }^{36}$

Since September 2001, numerous alternative venues to criminal trials have been proposed and sometimes used. The creation of a specialized national security court has been advocated by some on the political left and right as a means to professionalize and depoliticize the process of adjudicating terrorism trials while also protecting the classification of secret documents. ${ }^{37}$ However, such proposals have

31. Sudha Setty, Comparative Perspectives on Specialized Trials for Terrorism, 63 ME. L. REv. 131 (2010).

32. This reputation for a justice system with exceptionally strong protections for defendants is open to critique. See James Forman, Jr., Exporting Harshness: How the War on Crime Helped Make the War on Terror Possible, 33 N.Y.U. Rev. L \& Soc. Change 331, 337 (2009) ("we hav[e] one of the most punitive systems in the world while believing we have one of the most liberal").

33. Human Rights First, the Case Against a Special Terrorism Court 3 (2009) ("Unjust detentions and trials at Guantanamo have fueled animosity toward the United States. These decisions also have undermined U.S. efforts to advance the rule of law around the world, which is critical to confronting the threat of terrorism. Creating a special terrorism court ... would perpetuate these errors"). (2010).

34. Wadie E. Said, The Terrorist Informant, 85 WASH. L. REv. 687, 698-711

35. See Ctr. on Law \& Security, N.Y. Univ. Sch. of Law, Terrorist Trial RePORT CARD: September 11, 2001-SePtember 11, 2011, 26 (2011) available at http:// www.lawandsecurity.org/Portals/0/Documents/TTRC\%20Ten\%20Year\%20Issue.pdf.

36. See Paul Harris, Fake terror plots, paid informants: the tactics of FBI 'entrapment' questioned, theguardian.com, Nov. 16, 2011, available at http://www.theguard ian.com/world/2011/nov/16/fbi-entrapment-fake-terror-plots (arguing that the FBI has concocted terrorism plots, lured and enabled individuals to participate and then arrested them in order to justify the expansion of the government's counterterrorism powers).

37. See Jack Goldsmith and Neal Katyal, The Terrorists' Court, nytimes.com, July 11, 2007, available at http://www.nytimes.com/2007/07/11/opinion/11katyal.html ?_r=0. 
been met with concern and have not been implemented. The Bush administration made a decision soon after September 2001 to use military commissions to try those who were designated by the administration as "enemy combatants." The military commission system has been through several iterations in the intervening twelve years, but relatively few defendants have actually been tried in this system. ${ }^{38}$

\section{Punishment of Terrorism}

Prior to the passage of the AEDPA in 1996, sentencing for crimes involving terrorism fell within the range dictated under ordinary criminal law, since defendants usually faced charges based on violent criminal activity, regardless of any political motivations. Upon the passage of the Patriot Act, Congress authorized enhancements to the sentencing for numerous terrorism-related crimes. ${ }^{39}$ As a result, sentences for such crimes increased significantly, even in situations where there was no direct link to an act of violence, such as material support for terrorism. ${ }^{40}$ The existence of a terrorism sentencing enhancement also serves as a statutory basis for appellate courts to overturn sentences as too lenient, as has occurred in high-profile prosecutions, such as those of Ahmad Abu Ali, Lynne Stewart, and Jose Padilla. ${ }^{41}$

\section{Investigative Powers}

\section{A. Police Powers}

The USA PATRIOT Act and other legislation in the post-9/11 context increased the powers of federal law enforcement authorities such as the Federal Bureau of Investigation (FBI). This has led to increased surveillance and investigation, as well as a significant number of arrests of alleged terrorists. The government has maintained that its efforts have prevent planned terrorist acts from occurring ${ }^{42}$ and has elicited valuable counterterrorism and intelligence information as part of the interrogation, negotiation, and plea bargain process. ${ }^{43}$ The federal material witness statute, which em-

38. See Part IX.A, infra, for a discussion of the U.S. military commission system.

39. See U.S. SENTENCING GUIDELINES MANUAL, Appendix A (sentencing table) (2011).

40. The penalty for conviction is a sentence of up to fifteen years in prison, rising to life in prison if the material support results in death. 18 U.S.C. $\$ 2339 \mathrm{~B}$ (2006).

41. See United States v. Stewart, 686 F.3d 156 (2d Cir. 2012); United States v. Abu Ali, 528 F.3d 210 (4th Cir. 2008).

42. See, e.g., Sarah Kershaw, Terrorist in '99 U.S. Case is Sentenced to 22 Years, N.Y. Times (July 28, 2005), http://query.nytimes.com/gstlfullpage.htrn1?res=9A07 E7DCI03FF93BAI5754COA9639C8B63 (describing the detention of Ahmed Ressam two weeks prior to the execution of his planned attack).

43. See Jeff Zeleny \& Charlie Savage, Official Says Terrorism Suspect is Cooperating, N.Y.Times, Feb. 3, 2010, at A11 (noting that Umar Farouk Abdulmutallab, 
powers the government to detain and question individuals without charge $^{44}$ has enhanced the ability of law enforcement to detain individuals with potentially relevant information for terrorism prosecutions, but it has also increased the potential for abuse of discretion and abuse of executive power. ${ }^{45}$

For most ${ }^{46}$ covert counterterrorism-related surveillance, the FBI is obligated to follow requirements under the Foreign Intelligence Surveillance Act (FISA) to seek judicial approval from the Foreign Intelligence Surveillance Court (FISC). Under FISA, law enforcement officials must meet the standard of probable cause to garner a warrant for surveillance, a standard that the government meets in almost all cases. ${ }^{47}$ Law enforcement officers must undertake a minimization process by which they attempt to ensure that individuals and communications that are not targets of investigation are excluded from surveillance. ${ }^{48}$ Much of the information garnered pursuant to a FISC warrant is usable in court. FISA has been amended several times since its enactment in 1978, with the most recent amendments in 2008 allowing for broader surveillance authority and immunizing telecommunications companies that work with law enforcement to enable surveillance from civil liability. ${ }^{49}$

The FBI's police powers have also generated a high level of scrutiny of immigrant populations within the United States. The lowered due process protections accorded to immigrants allow for a more searching and a less privacy-protective approach. Lawyers cite the presence of FBI agents during immigration proceedings, Immigration and Custom Enforcement's (ICE) reliance on statements made in old FBI interviews in its decisions, and the FBI's submission of prejudi-

arrested in conjunction with his alleged attempt to use explosives on a United Statesbound airline flight on December 25, 2009, cooperated with law enforcement and offered valuable information pertaining to al-Qaeda).

44. See 18 U.S.C. $\$ 3144$ (2000).

45. The government used the material witness statute broadly after the terrorist attacks of September 11,2001, arresting hundreds of people and detaining them for up to several months. See. e.g., al-Kidd v. Ashcroft, 580 F.3d 949 (9th Cir. 2009); Elmaghraby v. Ashcroft, No. 04 CV 01809 JG SMG, 2005 WL 2375202, at *2 (E.D.N.Y. Sept. 27, 2005).

46. National Security Letters, used over 100,000 times by the Bush administration, circumvented judicial oversight altogether. Instead, they were subpoenas by the FBI seeking information on a target from third parties such as banks or employers, while implementing a gag order on the recipients of the subpoenas. See generally Shirin Sinnar, Protecting Rights from Within? Inspectors General and National Security Oversight, 65 Stan. L. REv. 1027 (2013).

47. See David Kravets, Domestic Surveillance Court Approved All 1,506 Warrant Applications in 2010, wired.com, May 6, 2011, available at http://www.wired.com/ threatlevel/2011/05/domestic-surveillance/.

48. See, e.g., 50 U.S.C. $\$ 1801(\mathrm{~h})(2006)$ (directing the use of minimization procedures to "minimize the acquisition and retention, and prohibit the dissemination, of nonpublicly available information concerning unconsenting United States persons").

49. Foreign Intelligence Surveillance Act of 1978 Amendments Act of 2008, Pub.L. 110-261 (enacted July 10, 2008). 
cial affidavits raising national security concerns without providing the basis of the allegations. FBI agents have used the structural power imbalances inherent in the immigration processes to coerce Muslim immigrants into becoming informants, or retaliate if they refuse. ${ }^{50}$

State and local police agencies have worked on counterterrorism issues, often in conjunction with federal law enforcement agencies. Joint Terrorism Task Forces (JTTFs) ${ }^{51}$ are arrangements in which a local police department assigns a number of officers to work on a terrorism-related task force with FBI agents; ${ }^{52}$ federal agents offer access to powerful investigative tools, whereas police departments offer local knowledge and engagement in community policing. ${ }^{53}$ Over one hundred American cities participate in JTTFs, ${ }^{54}$ despite occasional concerns that the JTTFs engage in unconstitutional racial and religious profiling. ${ }^{55}$ Municipalities like New York City have engaged in expansive counterterrorism work in the post-9/11 years that has raised significant concerns as the infringement of civil liberties. ${ }^{56} \mathrm{Fu}-$ sion centers are state and local entities meant to enhance the ability of the federal government to garner and synthesize information from local communities, ${ }^{57}$ but have been criticized for undermining civil liberties and wasting taxpayer funds. ${ }^{58}$

50. Ctr. for Human Rights and Global Justice, Asian Am. Legal Def. and Educ. Fund, Under the Radar: Muslims Deported, Detained, and Denied on Unsubstantiated Terrorism Allegations 8 (2011), available at http://aaldef.org/ UndertheRadar.pdf.

51. See Federal Bureau of Investigation, Protecting America from Terrorist Attack: Our Joint Terrorism Task Forces, fbi.com, available at http://www.fbi.gov/aboutus/investigate/terrorism/terrorism_jttfs (describing the role and structure of JTTFs).

52. See Tung Yin, Joint Terrorism Task Forces as a Window into the Security vs. Civil Liberties Debate, 13 Fla. Coastal L. Rev. 1, 3 (2012); Fed. Bureau of Investigation, Boston Joint Terrorism Task Force Memorandum of Understanding (2006), available at https://www.aclu.org/files/pdfs/spyfiles/ma_attachment3_attach_ MSP\&FBI2.pdf.

53. See James Forman, Jr., Community Policing and Youth as Assets, 95 J. CRIM. L. \& CRIminology 1, 9 (2004). For a cogent critique of the use of community policing in the counterterrorism context, see Sahar F. Aziz, Policing Terrorists in the Community, forthcoming Harvard National Security Journal (Fall 2013), available at http:// papers.ssrn.com/sol3/papers.cfm?abstract_id=2222083.

54. See Protecting America from Terrorist Attack, supra note 51.

55. See William Yardley, Portland, Ore., Votes to Rejoin Task Force After Terrorism Scare, nytimes.com, Apr. 30, 2011, available at http://www.nytimes.com/2011/05/ 01/us/01portland.html?_r=2\&ref=us\& (visited Sept. 27, 2013) (describing the civil liberties concerns behind the temporary refusal of Portland, Oregon to work with the FBI as part of a JTTF).

56. See generally Matt Apuzzo and Adam Goldman, Enemies Within: Inside the NYPD's Secret Spying Unit and bin Laden's Final Plot Against America (2013) (offering evidence of systematic religious profiling and discrimination by the New York City Police Department's counterterrorism unit).

57. See Department of Homeland Security, State and Major Urban Area Fusion Centers, available at http://www.dhs.gov/state-and-major-urban-area-fusion-centers.

58. See Senators Carl Levin and Tom Coburn, Federal Support for and Involvement in State and Local Fusion Centers, United States Senate Permanent 


\section{B. Intelligence Agencies}

The Central Intelligence Agency (CIA) and the National Security Agency (NSA), the leading intelligence-gathering organizations for the U.S. government, have operated with much greater latitude in the post-9/11 era than previously. ${ }^{59}$ The CIA has worked extensively to capture, detain and interrogate suspected terrorists abroad. It operated various secret detention facilities, known as "black sites," throughout the world to accomplish this goal, prompting criticism from international and domestic groups that people were being disappeared by the CIA. ${ }^{60}$ In 2009, the use of those black sites was curtailed by President Obama. ${ }^{61}$

In the post-9/11 era, the NSA has, among other programs, allocated tremendous energy and resources to massive data collection of electronic communications of U.S. and foreign persons. ${ }^{62}$ The NSA defends its collection of telephone call metadata and electronic communications based on the FISC's interpretation of section 215 of the Patriot Act. The FISC has created a nonpublic body of law that has allowed the NSA to amass the metadata (time, location, duration, and other information not containing content) for all domestic and some international phone calls. ${ }^{63}$ From June 2013 onward, as details of the breadth and depth of the NSA's surveillance programs continue to leak to the public, ${ }^{64}$ questions have arisen as to whether the scope of NSA's surveillance is an unconstitutional intrusion into the privacy of U.S. citizens, whether congressional oversight of the NSA

Subcommittee on Investigations Committee on Homeland Security and Governmental Affairs, Oct. 3, 2012.

59. The CIA is prohibited from conducting surveillance within U.S. borders. See Executive Order 12333, 46 Fed. Reg. 59941 (Dec. 4, 1981); National Security Act of 1947. However, the CIA has justified its surveillance within the U.S. by focusing its efforts on foreign targets that have contact with domestic sources, as well as assigning CIA officers on unpaid leave to work on domestic efforts. See Inspector General David B. Buckley, Review of CIA-NYPD Relationship, Dec. 27, 2011, available at https://www.documentcloud.org/documents/717864-cia-nypd-ig.html).

60. See Dafna Linzer and Julie Tate, New Light Shed on CIA's 'Black Site' Prisons, washpost.com, Feb. 28, 2007, available at http://www.washingtonpost.com/wpdyn/content/article/2007/02/27/AR2007022702214.html (visited Sept. 27, 2013).

61. Exec. Order No. 13,491, 74 Fed. Reg. 16,4893 (Jan. 22, 2009).

62. Timothy B. Lee, Here's everything we know about PRISM to date, washpost. com, June 12, 2013, available at http://www.washingtonpost.com/blogs/wonkblog/wp/ 2013/06/12/heres-everything-we-know-about-prism-to-date/ (visited Sept. 27, 2013).

63. Jennifer Valentino-Devries and Siobhan Gorman, Secret Court's Redefinition of 'Relevant' Empowered Vast NSA Data-Gathering, WALL ST. J., July 8, 2013, available at http://online.wsj.com/article/SB100014241278873238739045785718937588533 44.html.

64. Former CIA contractor Edward Snowden began disclosing numerous aspects of NSA surveillance practices in June 2013. See Glenn Greenwald, NSA collecting phone records of millions of Verizon customers daily, theguardian.com, June 5, 2013, available at http://www.theguardian.com/world/2013/jun/06/nsa-phone-records-veri zon-court-order. 
must be strengthened, ${ }^{65}$ and whether the FISC provides an effective mechanism to curb potential abuse by the NSA. ${ }^{66}$

These debates continue to be robust, largely due to the impact of these counterterrorism programs on a vast swath of the U.S. public and because of the seeming inability of the public to understand the program and curtail it. This frustration stems from the secrecy surrounding the program, Congress's inability to disclose the extent of its knowledge to the public or exercise substantial oversight, FISC not being able to take an adversarial position with regard to government assurances of the necessity of such surveillance, and the extent of NSA access to the data stored by telecommunications companies, even without their consent. 67 In response to the public debate, task forces were convened to examine the scope and legality of the NSA's work. ${ }^{68}$ As of early 2014, Congress and the administration continue to weigh various options for reforming both intelligence-gathering and storage policies, as well as oversight and accountability measures. ${ }^{69}$

65. See Spencer Ackerman, Intelligence committee withheld key file before critical NSA vote, Amash claims, guardian.com, Aug. 12, 2013, available at http://www.the guardian.com/world/2013/aug/12/intelligence-committee-nsa-vote-justin-amash (noting that congressional leaders had not shared the relevant information with their colleagues prior to voting for Patriot Act reauthorization).

66. See Carol D. Leonnig, Court: Ability to police U.S. spying program is limited, washingtonpost.com, Aug. 15, 2013, available at http://www.washingtonpost.com/ politics/court-ability-to-police-us-spying-program-limited/2013/08/15/4a8c8c44-05cd-1 1e3-a07f-49ddc7417125_story.html (citing U.S. district judge Reggie Walton and noting that "the court lacks the tools to independently verify how often the government's surveillance breaks the court's rules ... [and] it also cannot check the veracity of the government's assertions that the violations its staff members report are unintentional mistakes").

67. See Nicole Perlroth, Jeff Larson and Scott Shane, N.S.A. Able to Foil Basic Safeguards of Privacy on Web, N.Y. Times, Sept. 6, 2013, at A1 (discussing NSA efforts to make encryption software vulnerable, and noting that much of this activity has been sanctioned by the FISC).

68. See Privacy and Civil Liberties Oversight Board, Report on the Telephone Records Program Conducted Under Section 215 of the USA PATRIOT Act and on the Operations of the Foreign Intelligence Surveillance Court, Jan. 23, 2014, available at http://www.pclob.gov/SiteAssets/Pages/default/PCLOB-Report-on-the-Telephone-Rec ords-Program.pdf (concluding that some aspects of the NSA's surveillance program were likely illegal); President's Review Group on Intelligence and Communications Technologies, Liberty and Security in a Changing World, Dec. 12, 2013, available at http://www.whitehouse.gov/sites/default/files/docs/2013-12-12_rg_final_report.pdf (recommending some changes to the NSA's data collection and storage procedures).

69. President Obama has spoken out on the importance of the NSA's work in developing actionable intelligence, as well as the need to revisit the question of limitations on the NSA's collection and storage of data. See President Barack Obama, Remarks by the President on Review of Signals Intelligence, whitehouse.gov, Jan. 17, 2014, available at http://www.whitehouse.gov/the-press-office/2014/01/17/remarkspresident-review-signals-intelligence (visited Feb. 26, 2014). 


\section{Proscription/Listing of Terrorist Groups/Individuals}

\section{A. Proscription Mechanisms}

The ability of the Secretary of State to designate "foreign terrorist organizations" (FTOs) as such for the purposes of prohibiting material support, increasing surveillance and freezing financial assets has been an important tool for U.S. counterterrorism efforts. ${ }^{70} \mathrm{In}$ particular, U.S. law provides that incitement to commit a terrorist act (under circumstances indicating an intention to cause death or serious bodily injury) is a basis for designating a group as either an FTO $^{71}$ or as a terrorist organization for immigration purposes. ${ }^{72}$ Even if a group has not been formally designated as an FTO, if the requisite incitement standard is met, that automatically triggers treatment as a terrorist organization for immigration purposes. ${ }^{73} \mathrm{Ob}$ servers suggest that the FTOs fall into one of two categories: those that genuinely threaten the national security of the United States in a direct way, and those that challenge the foreign relations or economic interests of the United States. ${ }^{74}$

Under the AEDPA, a specific process must be undertaken to designate an organization as an FTO. ${ }^{75}$ It is a process that is open to critique as being insufficiently rights-protective, but also incorporates some safeguards against abuse. ${ }^{76}$ Once the FTO designation has been made by the State Department, limited procedural safeguards are available, after which the designation is finalized. ${ }^{77}$

70. U.S. 2006 CTC Report, supra note 17 , at 8.

71. 8 U.S.C. $\$ 1189$.

72. 8 U.S.C. $\S 1182(a)(3)(B)(v i)(I I)$ (provided that other relevant legal criteria are met).

73. 8 U.S.C. $§ 1182(a)(3)(B)(v i)(I I I)$.

74. Wadie E. Said, The Material Support Prosecution and Foreign Policy, 86 InD. L.J. 543, 568 (2011).

75. See AEDPA $\S \S 219(\mathrm{a})(1)(\mathrm{A})-(\mathrm{C}), 219(\mathrm{a})(2)(\mathrm{C})$ (codified in 8 USC $\S 1189(\mathrm{a})$ ) (finding that anyone who interacts with FTOs is violating the statute, and authorizing the Secretary of the Treasury to freeze the assets of entities designated as FTOs); Exec. Order No. 12,947, 3 C.F.R. 319 (1995) (establishing authority for the Secretary of State and the Secretary of the Treasury to limit property rights of designated terrorists). See also Exec. Order No. 13,224, 3 C.F.R. 786 (2002) (finding it necessary to utilize financial sanctions against foreign terrorists).

76. See AEDPA $\S 219$ (a) (codified as 8 U.S.C. $\$ 1189(\mathrm{a})$ ) (establishing both the procedure used for designation as a terrorist organization as well as congressional and judicial means available to pursue designations review and revocation); see also Julie B. Shapiro, The Politicization of the Designation of Foreign Terrorist Organizations: The Effect on Separation of Powers, 6 CARdozo Pub. L. Pol'y \& ETHICs J. 547, 556-58 (2008) (arguing that the designation process contravenes due process guarantees).

77. Under AEDPA, the Secretary of State notifies leaders in Congress and gives notice to designees in the Federal Register. AEDPA $\S 302(a)(2)(A)$ (codifed as 8 U.S.C. $\S 1189(\mathrm{a})(2)(\mathrm{A}))$. FTOs then have 30 days to challenge their designation in the U.S. Court of Appeals for the District of Columbia Court. § 302(b). Such cases, usually based on allegations of an abuse of discretion by the State Department or a lack of substantial support for the FTO designation, are largely unsuccessful. E.g., People's Mojahedin Org. of Iran v. Dep't of State, 327 F.3d 1238, 1244 (D.C. Cir. 2003) (uphold- 
Because the consequences of FTO designation can be severe, including the ability of financial intuitions to block or freeze assets of an FTO, ${ }^{78}$ the barring of FTOs from entry into the United States, ${ }^{79}$ and potential material support charges, ${ }^{80}$ the procedural safeguards are even more important. ${ }^{81}$ FTO designation carries with it mandatory review and renewal process for the Secretary of State. ${ }^{82}$

\section{B. Challenges to Proscriptions and Listings}

Another such safeguard in the FTO designation process is the opportunity to contest the designation proposed by the State Department. This layer of judicial review protects against arbitrariness in the designation, ${ }^{83}$ and requires some disclosure of the basis upon which the State Department made its determination. ${ }^{84}$

Designated groups may challenge their designations by seeking judicial review before the D.C. Circuit Court within thirty days of the designation being published in the Federal Register. The court may rely only on the administrative record generated by the Secretary of State and the Secretary of State may supplement this record on an ex parte basis with classified information used in making the designation. ${ }^{85}$ The D.C. Circuit has the right to reverse if the designation is found to be not in accord with the procedures required by law. The FTO designation remains in force until it is revoked by either judicial or administrative review. In either case, the burden lies with the FTO to challenge its designation.

ing FTO designation based on classified evidence and emphasizing deference to the State Department in the FTO designation process).

78. 18 U.S.C. $\$ 2339 B(a)(2)(2006)$.

79. 8 U.S.C. $\S \S 1182(\mathrm{a})(3)(\mathrm{B})(\mathrm{i})(\mathrm{IV})-(\mathrm{V})(2006)$.

80. 18 U.S.C. $\S 2339 B(a)(1)$ (2006). The constitutionality of the FTO designation process authorized by Executive Order No. 13,224 and various statutes was upheld by the U.S. Supreme Court in Humanitarian Law Project v. Holder. Holder v. Humanitarian Law Project, 130 S. Ct. 2705 (2010).

81. See Nat'l Council of Resistance of Iran v. Dep't of State, 251 F.3d 192, 196 (D.C. Cir. 2001) (discussing the severe impact of FTO designation).

82. 8 U.S.C. $\$ 1189(a)(4)(C)$, (a)(6) (2006). If no review has been made of an FTO designation for five years, the Secretary of State must review the listing to determine whether it should be revoked due to a change in the organization's mission and actions, or a change in the national security assessment by the United States. See id.

83. Under the AEDPA, courts have the power to set aside the State Department designation of an FTO if it is arbitrary, capricious, and an abuse of discretion, or if it is not based on substantial evidence. AEDPA $\$ 302(\mathrm{~b})(3)$ (codified as 8 U.S.C. $\S 1189(\mathrm{c})(3))$. Courts have, however, been extremely deferential to the State Department, choosing not to review classified evidence in some instances, but relying instead on State Department affirmations of substantial evidence to support its designation decision. E.g., People's Mojahedin Org. of Iran, 327 F.3d at 1244.

84. E.g., People's Mojahedin Org. of Iran v. United States Dep't of State, 613 F.3d 220, 231 (D.C. Cir. 2010) (holding that the government had violated due process by failing to give an FTO the opportunity to view unclassified evidence prior to making a final decision denying petition to revoke designation as an FTO).

85. See Said, Material Support Prosecution, supra note 74, at 559. 


\section{Regulation of Terrorism Financing}

\section{A. The Regulatory Regime to Counter Terrorism Financing}

Executive Order 13224 was signed by President George W. Bush in September 2001 with the stated purpose of disrupting and destroying financial support for al-Qaeda. ${ }^{86} \mathrm{~A}$ number of policies designed to minimize and disrupt terrorist financing have become important tools in U.S. counterterrorism strategy. These policies are implemented largely by the Treasury Department, ${ }^{87}$ with support from the State Department and Justice Department. The Office of Intelligence and Analysis (OIA) within Treasury Department was created in 2004, making the Treasury Department the only finance ministry in the world with its own in-house intelligence unit. Separately, Treasury Department's Office of Terrorism and Financial Intelligence (TFI) members chair the U.S. delegation to the Financial Action Task Force, an intergovernmental body that develops and promotes policies to combat illicit finance. ${ }^{88}$

Title III of the Patriot Act amended the Bank Secrecy Act to require certain financial institutions and businesses to establish antimoney laundering programs .89 The government also sought to encourage transparency, good corporate governance and strong antimoney laundering programs through suggesting that public and media attention will cause social stigma to attach to businesses that engage with entities that are associated with criminal or terrorist activity. ${ }^{90}$ U.S. authorities have prioritized the investigation and disruption of funding to non-profit organizations, and have used the material support statutes as an effective, if highly controversial, tool to hinder the ability of terrorist groups to maintain their finances. The robust use of material support statutes has caused such solicitation to wither or, in some cases, go further underground. ${ }^{91}$

The Department of Justice is the principal government entity responsible for overseeing the investigation and prosecution of money

86. Executive Order 13224 of Sept. 23, 2001: Blocking Property and Prohibiting Transactions With Persons Who Commit, Threaten to Commit, or Support Terrorism (citing both domestic authority and United Nations Security Council Resolution (UNSCR) 1214, UNSCR 1267, UNSCR 1333, and UNSCR 1363 as supportive authority).

87. The Treasury Department's Office of Terrorism and Financial Intelligence (TFI) coordinates these efforts. The TFI consists of four sub-groups: the Financial Crimes Enforcement Network (FinCEN), the Office of Foreign Assets Control (OFAC), the Office of Terrorist Financing and Financial Crimes (TFFC), and the Office of Intelligence and Analysis (OIA). Third Mutual Evaluation Report on Anti-Money Laundering And Combating The Financing of Terrorism: United States of America, (Financial Action Task Force, Paris, France) June 2006, at 15-16 [hereinafter June 2006 Financing Report] available at http://www.fatf-gafi.org/countries/u-z/united states/documents/mutualevaluationoftheunitedstates.html.

88. Id. at 4 .

89. Id.

90. Id. at 5 .

91. Id. at 8 . 
laundering and terrorist financing offenses at the federal level, whereas the State Department represents the U.S. government in several multilateral institutions, including those exercising sanctions related to U.N. Security Council Resolution 1267 and Counter-Terrorism Committees. ${ }^{92}$

The State Department's Office of the Coordinator for Counterterrorism leads its efforts to designate FTOs in order to freeze assets and preparing Executive Order 13224 designations to block assets and prohibit contributions of terrorists and terrorist organizations. ${ }^{93}$

\section{B. Criminal Offences of Terrorism Financing}

The issues of what standards of knowledge and intent are necessary to sustain a conviction for material support of terrorism have been extensively litigated. The 2010 Supreme Court decision in Holder $v$. Humanitarian Law Project affirmed the constitutionality of the material support statute, thereby upholding the congressional intent to criminalize almost all support to FTOs, even if the funds were earmarked for humanitarian-not terrorism-purposes. ${ }^{94}$

The four federal offenses deal directly with financing of terrorism or terrorist organizations and criminalize the provision of material support for the commission of certain offenses, ${ }^{95}$ provision of material support or resources to designated FTOs, ${ }^{96}$ provision or collection of terrorist funds, ${ }^{97}$ and the concealment or disguise of either material support to FTOs or funds used or to be used for terrorist acts. ${ }^{98}$

\section{Immigration MeAsures}

\section{Immigration Detention}

The government is authorized to detain any person for whom it has certified that reasonable grounds exist to believe that the person has engaged in espionage, ${ }^{99}$ opposition by violence, ${ }^{100}$ or terrorist activity, ${ }^{101}$ or is involved with an organization that is suspected of

92. Id. at 17.

93. Id. at 19 .

94. Holder v. Humanitarian Law Project, 130 S. Ct. 2705 (2010).

95. 18 USC 2339A (enacted in 1994, effective in 1996).

96. 18 USC 2339B (enacted by Congress and signed by the President in April 1996, and implemented with State Department designations of FTOs on Oct. 81997).

97. 18 USC 2339C(a) (enacted 25 June 2002).

98. 18 USC 2339C(c) (enacted 25 June 2002).

99. Immigration and Naturalization Act ("INA") $\$ 237($ a)(4)(A)(i) (authorizing detention for those suspected of engaging in espionage, sabotage, or export control).

100. INA $\$ 237(\mathrm{a})(4)(\mathrm{A})(\mathrm{iii})$ (authorizing detention for those expressing opposition by violence or overthrow of the U.S. government).

101. INA $\S 212(\mathrm{a})(4)(\mathrm{B})$ (authorizing detention for those suspected of terrorist activity); 8 U.S.C. $\$ 1182(a)(3)(B)(i)(I I I)$ and (iv)(I) (authorizing removal of those indicating an intention to cause death or serious bodily harm or have incited terrorist activity); 8 
terrorist activity. ${ }^{102}$ The Attorney General may detain the suspect for up to seven days prior to placing the suspect in removal proceedings or charging him or her criminally. ${ }^{103}$ If the suspect is not placed in removal proceedings or criminally charged, the Attorney General must release him or her, but if placed in proceedings, the Attorney General must detain the person even if he or she is eligible for relief or obtains relief until the Attorney General determines that there is no longer any reason to believe that the person falls under one of the bases for certification. ${ }^{104}$ The Attorney General is obligated to review the certification subjecting the person to mandatory detention every six months and the detainee may request review every six months and may submit documents and other evidence in support of his or her request. ${ }^{105}$ A detainee who has been ordered removed, but whose removal is unlikely in the reasonably foreseeable future, may be detained for additional six month periods only if the government believes that release will threaten national security or the safety of the community or any person. 106

Since September 11, 2001, the federal government has relied heavily on immigration law and policy to detain, interrogate, control and remove suspected terrorists. ${ }^{107}$ With fewer checks and balances, it is much easier for the government to arrest, detain, and investigate an individual under immigration law than criminal law. Unlike the U.S. criminal justice system, where defendants have the right to an attorney, the right to a speedy trial, and the presumption of innocence until guilt is proven beyond a reasonable doubt, immigration law does not afford detainees ample protections. For example, a noncitizen is permitted to have an attorney in immigration proceedings, but counsel is not provided for the $80 \%$ of detainees in removal proceedings who are indigent. Furthermore, a non-citizen can be mandatorily detained for months, or even years, before being released or removed from the United States, and the standard for

U.S.C. $\$ 1182(a)(3)(B)(i)(V I)$ (making inadmissible aliens who endorse or espouse terrorist activity or persuade others to endorse or espouse terrorist activity).

102. See 8 U.S.C. $\$ 1182(\mathrm{a})(3)(\mathrm{B})(\mathrm{vi})(\mathrm{II})$ or (III). See also U.S. CTC Response 2006, supra note 17, at 8 (noting that "if a group is designated or treated as a terrorist organization for immigration purposes, aliens having certain associations with the group (including persons who knowingly provide material support to the group) become inadmissible to and deportable from the United States").

103. INA $\S 236(\mathrm{a})(5)$.

104. INA $\S \S 236(\mathrm{a})(2),(5)$.

105. INA $§ 236 \mathrm{~A}(\mathrm{a})(7)$.

106. INA $\S 236 \mathrm{~A}(\mathrm{a})(6)$.

107. In 2009, Immigration and Customs Enforcement (ICE) had over 1.6 million aliens in its scope of monitoring: in ICE detention centers, in other jails or prisons, or under a released monitoring system. See Department of Homeland Security Office of the Inspector General, Supervision of Aliens Commensurate With Risk, OIG 11-81 (Dec. 2011) (hereinafter DHS 2011 IG Report), at 3. 
removal is that of "clear and convincing evidence," a much lower standard than that of reasonable doubt. ${ }^{108}$

These lesser protections have allowed federal officials to undertake several initiatives that have targeted immigrants, primarily those from Muslim-majority countries, in the name of national security. Muslims in the immigration system have been subjected to possibly abusive ${ }^{109}$ preventive detention, ${ }^{110}$ exclusion based on political views, heightened surveillance and arguably unconstitutional racial profiling. ${ }^{111}$ Detainees in the immigration system face serious hurdles in challenging the government's case for removal due to the lower removal standard of "clear and convincing evidence" as well as the inability to access and challenge the secret evidence presented and alleged by the government. ${ }^{112}$

The government has, to some extent, conflated immigration and counterterrorism programs and has encouraged use of the immigration system as an important tool in counterterrorism efforts. ${ }^{113}$ The result has been a system that, although legal under U.S. law, ${ }^{114}$ arguably violates international law and norms with regard to the treatment of migrants. ${ }^{115}$

108. INA $\$ 240(\mathrm{c})(3)(\mathrm{A})$.

109. See Ashcroft v. Iqbal, 556 U.S. 662, 667-69 (2009).

110. Another category of detained aliens are those subject to an additional interagency screening called Third Agency Check. This system to screen aliens in ICE custody who are from specially designated countries (SDCs) that have "shown a tendency to promote, produce, or protect terrorist organizations or their members." See DHS 2011 IG Report, supra note 105, at 5. The SDC list is largely comprised of majority Muslim nations. See ICE List of Specially Designated Countries (SDCs) that Promote or Protect Terrorism, publicintelligence.net, July 2, 2011, available at http:// publicintelligence.net/specially-designated-countries/ (listing the SDCs that were originally part of the DHS 2011 IG Report, but which were subsequently removed from that publication).

111. See Under the Radar, supra note 50, at 4 (discussing various programs targeting non-citizens, including Absconder Apprehension Initiative, NSEERS special registration policy, and Operation Frontline). Another controversial immigration policing program is Secure Communities, which requires state and local police to send fingerprints of arrestees to ICE so that undocumented immigrants can be identified and possibly detained, prosecuted and removed. See Immigration and Customs Enforcement, Secure Communities, ice.gov (describing the Secure Communities program), available at http://www.ice.gov/secure_communities/ (visited Sept. 13, 2013).

112. See Under the Radar, supra note 50, at 4.

113. See, e.g., Attorney General John Ashcroft and INS Commissioner Jim Ziglar, Announcement of INS Restructuring Plan (November 14, 2001), available at http:// www.justice.gov/archive/ag/speeches/2001/agcrisisremarks11_14.htm ("The INS will also be an important part of our effort to prevent aliens who engage in or support terrorist activity from entering our country.").

114. See DHS 2011 IG Report, supra note 107, at 1 (noting that immigration authorities had generally complied with applicable domestic laws).

115. See Under the Radar, supra note 50, at 18 (citing the conclusion of the U.N. Special Rapporteur on the Rights of Migrants that U.S. immigration enforcement policies violate international laws that bar arbitrary detention). 


\section{Administrative/Executive Measures}

The AUMF and Patriot Act cemented the government's authority to determine whether information was too sensitive to disclose and then punish those who disclosed such information. ${ }^{116}$ More recently, Congress enacted the National Defense Authorization Act of 2012, which empowered the President to take extraordinary national security measures unilaterally and enabled further non-disclosure of information by the administration and military. ${ }^{117}$

One area in which the tensions between secret, unilateral executive action and the desire for a public, multi-branch course of action has been most prominent is that of targeted killings. The U.S. use of unmanned aerial vehicles ("drones") for targeted killings ${ }^{118}$ of suspected terrorists has expanded significantly since President Obama took office in 2009.119 The Obama administration has consistently emphasized the necessity, efficacy and legality of targeted killings. However, the program has prompted much debate over its existence, ${ }^{120}$ the moral calculus ${ }^{121}$ and legal parameters and authorities for such a program, ${ }^{122}$ and specific questions regarding the legality of

116. See USA PATRIOT Act of 2001, Pub. L. No. 107-56, § 215, 115 Stat. 272 (codified in scattered sections of 50 U.S.C.) (disallowing the dissemination of information regarding any business records that are sought pursuant to terrorism investigations); $i d$. $\S 223$ (codified in scattered sections of 18 U.S.C.) (permitting civil liability and administrative disciplinary measures against individuals who make unauthorized disclosures of information); id. § 116 (prohibiting disclosure to individuals involved in suspicious activities that such activity was reported pursuant to the issuance of a National Security Letter).

117. National Defense Authorization Act for Fiscal Year 2012, Pub. L. No. 112-81, $\$ 1025$ (2011) (limiting the types of information, forms of communication, and representation available to detainees).

118. Although targeted killings is not defined under international law, it is often considered to encompass "premeditated acts of lethal force employed by states in times of peace or during armed conflict to eliminate specific individuals outside their custody." See Jonathan Masters, Targeted Killings, Council on Foreign Relations, May 23, 2013, available at http://www.cfr.org/counterterrorism/targeted-killings/ p9627 (visited July 18, 2013). Although the governments that utilize targeted killings differentiate them from assassinations, see Harold Hongju Koh, The Obama Administration and International Law, Mar. 25, 2010, available at http://www.state.gov/s/l/ releases/remarks/139119.htm, critics view them as similar actions in terms of illegality. See, e.g., Complaint, Al-Aulaqi, et al. v. Panetta, at I1, Case 1:12-cv-01192-RMC (D.D.C. July 18, 2012).

119. See New America Foundation, Drone Database, available at http://natsec. newamerica.net/about (visited July 18, 2013) (detailing the number of drone strikes by the United States in Yemen and Pakistan since 2004).

120. See, e.g., Philip Alston, Report of the Special Rapporteur on extrajudicial, summary or arbitrary executions: Study on Targeted Killings, A/HRC/14/24/Add.6, May 28,2010 (questioning the legality of the CIA drone program).

121. See generally Samuel Isaacharoff \& Richard H. Pildes, Drones and the Dilemma of Modern Warfare, available at http://ssrn.com/abstract=2268596 (visited July 31,2013 ) (theorizing the moral dilemma of drone use in the context of warfare in which geographic and other traditional boundaries of violence are distorted).

122. See Alston, supra note 118, at Add.6, May 28, 2010 (discussing international law of war principles with regard to targeted killings); e.g., Eric Holder, Attorney General Eric Holder Speaks at Northwestern University School of Law, Mar. 5, 2012, 
its scope in terms of geographic location of the target and citizenship of the target. ${ }^{123}$ The parameters and future of the targeted killings program should be considered in the context of two Obama administration positions as to the nature of the battle being fought: first, the assertion that the theater of war for U.S. counterterrorism efforts is not restricted geographically and, therefore, encompasses the entire globe; ${ }^{124}$ and second, statements made by administration officials in early 2013 that although the country should not remain on a war footing permanently, current counterterrorism efforts will likely last another ten to twenty years. ${ }^{125}$

The parameters of the targeted killing program remain largely shielded from public view, with limited information disclosed during President Obama's first term ${ }^{126}$ and the leak of a classified Department of Justice memorandum detailing some of the legal bases for the program. ${ }^{127}$ In early 2012, Attorney General Holder's public statement on drone use made clear that the administration was not bound geographically, that U.S. citizenship was no protection against being included on the list of targets for a drone strike, and that no judicial process was constitutionally necessary to target U.S. citizens so long as the administration followed its own careful procedures of determining whether to target a citizen. ${ }^{128}$

In May 2013, President Obama gave his second ${ }^{129}$ major national security policy speech, discussing a number of national security and foreign policy priorities, but focusing in large part on the

available at http://www.justice.gov/iso/opa/ag/speeches/2012/ag-speech-1203051.html (outlining the parameters used by the Obama administration to determine whether a targeted killing comports with international and domestic legal obligations).

123. See Al-Aulaqi v. Obama, 727 F. Supp. 2d 1 (D.D.C. 2010) (dismissing, based on standing grounds, the suit of Nasser al-Aulaqi to enjoin the U.S. government from keeping his son, U.S. citizen Anwar al-Aulaqi, on its targeted killing list).

124. Spencer Ackerman, Spec Ops Chief Sees '10 to 20 Years' More for War Against al-Qaida, wired.com, May 16, 2013, available at http://www.wired.com/dangerroom/ 2013/05/decades-of-war/ (visited July 18, 2013) (discussing the Senate testimony of Michael Sheehan, the assistant secretary of defense for special operations and lowintensity conflict, with regard to the global theater of war).

125. Id. (relating the Senate testimony of Michael Sheehan, the assistant secretary of defense for special operations and low-intensity conflict, with regard to the probable duration of the U.S. counterterrorism effort against al-Qaida).

126. E.g., John O. Brennan, Remarks of John O. Brennan: Strengthening our Security by Adhering to our Values and Laws, Sept. 16, 2011, available at http://www. whitehouse.gov/the-press-office/2011/09/16/remarks-john-o-brennan-strengtheningour-security-adhering-our-values-an (visited July 24, 2013); Koh, supra note 116.

127. Department of Justice White Paper, Lawfulness of a Lethal Operation Directed Against a U.S. Citizen Who is a Senior Operational Leader of Al-Qa'ida or An Associated Force, available at http://msnbcmedia.msn.com/i/msnbc/sections/news/02 0413_DOJ_White_Paper.pdf (visited July 24, 2013) [hereinafter DOJ White Paper].

128. See Holder, supra note 120.

129. President Obama gave his first major speech on national security in 2009. See Remarks by the President on National Security, May 21, 2009, available at http:// www.whitehouse.gov/the-press-office/remarks-president-national-security-5-21-09 (hereinafter "2009 National Archives Speech"). 
parameters of the administration's targeted killing program. ${ }^{130}$ In it, he argued that the use of drones to kill suspected terrorists is effective, legal and necessary, yet also acknowledged legal, foreign policy and political constraints on the program. ${ }^{131}$ Some critics were disappointed that the speech did not place additional meaningful limits on the president's authority to use drones, and that the president's promises of transparency and adequate oversight were unsupported by specific details or plans. ${ }^{132}$

\section{Role of Military and Extra-Territorial Counter- Terrorism Activities}

\section{A. Military Courts and Detention}

The Bush administration decided immediately after the September 11 attacks to detain suspected terrorists as unlawful enemy combatants - often at the U.S. military facility in Guantanamo Bay, Cuba-and to try them, if at all, before a military commission. ${ }^{133}$ Such detention would not necessarily comport with international standards, and any commissions would be administered by the executive branch and would not necessarily include the protections mandated by the Uniform Code of Military Justice for the courts martial system. ${ }^{134}$

130. Remarks by the President at the National Defense University, May 23, 2013, available at http://www.whitehouse.gov/the-press-office/2013/05/23/remarks-president-national-defense-university (hereinafter "May 2013 NDU Speech").

131. Id.

132. E.g., Glenn Greenwald, Obama's speech: seeing what you want to see, theguardian.com, May 27, 2013, available at Fred Kaplan, Obama's Post-9/11 World, slate. com, May 23, 2013, available at http://www.theguardian.com/commentisfree/2013/ may/27/obama-war-on-terror-speech (visited August 12, 2013) (arguing that President Obama's speech was mostly rhetoric meant to appease critics from a variety of political perspectives); http://www.slate.com/articles/news_and_politics/war_stories/ 2013/05/barack_obama_national_defense_university_speech_nothing_new_about_ drones.html (visited July 18, 2013) (noting that President Obama's speech outlined limits that were almost identical to those already in place and that the Justice Department had defined those limitations in ways that rendered the restrictions "meaningless"). Some politically conservative critics asserted that President Obama's speech consisted largely of rhetoric to appease liberal voters concerned about the administration's use of drones, but that Obama's substantive policy and approach to executive power was similar to that of President George W. Bush. See, e.g., Benjamin Wittes, The President's Speech: A Quick and Dirty Reaction-Part 1 (Are We At War?), Lawfare Blog, May 23, 2013, available at http://www.lawfareblog.com/2013/05/thepresidents-speech-a-quick-and-dirty-reaction-part-1/.

133. Military Order of November 13, 2001, 66 Fed. Reg. 57833 (Nov. 13, 2001).

134. See Setty, Specialized Trials, supra note 31, at 142-43 (discussing the ways in which the procedural protections offered to detainees in the military commission system deviated from the Uniform Code of Military Justice). 


\section{Detention at the Guantánamo Bay Facility}

In designating the Guantánamo Bay, Cuba military facility ${ }^{135}$ to hold detainees, the Bush Administration made an overt choice to seek to evade the domestic legal protections that would run to detainees held on U.S. soil, ${ }^{136}$ including access to habeas corpus hearings. ${ }^{137}$ The government further denied the applicability of international human rights and humanitarian norms and international law more generally, as applied to the detainees held at Guantánamo. ${ }^{138}$ When the Supreme Court held that the U.S. habeas corpus statute encompassed the indefinite detention of detainees at Guantánamo, ${ }^{139}$ the administration convinced Congress to amend that statute to deny all detainees the right to habeas corpus, even those who had already filed claims in court. ${ }^{140}$ In the 2008 Boumediene $v$. Bush decision, the Supreme Court ruled that Congress and the President could not decide that detainees at Guantánamo had no access to the law. ${ }^{141}$ Since then, most captured detainees have been taken to other locations, such as the Bagram Air Force base in Afghanistan, where courts have held that detainees have no habeas rights. ${ }^{142}$

Since 2002, 779 men have been taken to the naval base in Guantánamo Bay, Cuba, ${ }^{143}$ and 155 remained there as of February 2014. ${ }^{144}$ There have been consistent reports of widespread abuse, torture, and violations of the prisoners' human rights. ${ }^{145}$ Almost twothirds of the prisoners joined a months-long hunger strike in 2013,

135. For a thoughtful and detailed assessment of the role of the Guantánamo Bay military facility in U.S. history and foreign policy, see Ernesto Hernandez-Lopez, Guantánamo as Outside and Inside the U.S.: Why is a Base a Legal Anomaly?, 18 Am. U. J. Gender Soc. Pol'y \& L. 471 (2010).

136. See Rasul v. Bush, 542 U.S. 466, $497-98$ (2004) (Scalia, J., dissenting).

137. David Cole, The Taint of Torture: the Roles of Law and Policy in Our Descent to the Dark Side, 49 Hous. L. REv. 53, 65 (2012).

138. See Memorandum from Jack L. Goldsmith III, Assistant Attorney Gen., Office of Legal Counsel, to Alberto R. Gonzales, Counsel to the President, "Protected Person" Status in Occupied Iraq Under the Fourth Geneva Convention 23 (Mar. 18, 2004), available at http://www.justice.gov/olc/2004/gc4mar18.pdf).

139. See Rasul v. Bush, 542 U.S. 466, 484 (2004).

140. See Military Commissions Act of 2006, Pub. L. No. 109-366, §7, 120 Stat. 2600, 2635-36 (codified as amended at 28 U.S.C. §2241(e) (1) (2006)).

141. See Boumediene v. Bush, 533 U.S. 723, 785 (2008) ("The Constitution grants Congress and the President the power to acquire, dispose of, and govern territory, not the power to decide when and where its terms apply.").

142. See Al-Maqaleh v. Gates, 605 F.3d 84 (D.C. Cir. 2010).

143. Amnesty Int'L, USA: 'I am FAllen into daRKness'. Obaidullah, Guantánamo DETAINEE IN HIS 12TH YEAR WITHOUT TRIAL 1 (2013) available at http://www.amnesty usa.org/sites/default/files/amr510512013en.pdf.

144. See Human Rights Watch, Facts and Figures: Military Commissions v. Federal Courts, available at http://www.hrw.org/features/guantanamo-facts-figures (visited Feb. 26, 2014).

145. See, e.g., Ctr. for Constitutional Rights, Report on Torture and Cruel, Inhumane, and Degrading Treatment of Prisoners at Guantánamo Bay, Cuba (2006) available at http://ccrjustice.org/files/Report_ReportOnTorture.pdf. 
which led to military resorting to force-feeding several prisoners. ${ }^{146}$ Federal district courts declined to intervene on behalf of the prisoners, despite widespread condemnation by the United Nations and international human rights groups that the force-feeding constitutes torture. ${ }^{147}$ The government changed its policy in December 2013 such that it will no longer disclose to the public whether detainees are participating in hunger strikes. ${ }^{148}$ President Obama recommitted to closing the Guantánamo Bay in May 2013, ${ }^{149}$ after failing to fulfill the promise to do so when he took office in $2009 .{ }^{150}$

\section{Access to Justice}

The United States Supreme Court, in a series of cases from 2004 to $2008,{ }^{151}$ found various aspects of the administration's detention and military commission model to be unconstitutional. However, the Supreme Court consistently found that the use of military commissions instead of the ordinary criminal justice system was constitutionally acceptable. ${ }^{152}$

Supreme Court jurisprudence set a minimum guarantee of constitutional rights to be available to detainees, such as that of habeas corpus, but curtailing certain procedural and substantive protections in a military commission system is acceptable. ${ }^{153}$ After initially sug-

146. Ann E. Marimow, Judge Rejects Request to Block Force-feeding of Guantanamo Bay Detainees, WASH. Post (July 16, 2013), http://articles.washingtonpost.com/ 2013-07-16/national/40606715_1_hunger-strike-detainees-force-feeding.

147. See United Nations Human Rights, IACHR, UN Working Group on Arbitrary Detention, UN Rapporteur on Torture, UN Rapporteur on Human Rights and Counter-Terrorism, and UN Rapporteur on Health reiterate need to end the indefinite detention of individuals at Guatánamo Naval Base in light of current human rights crisis, May 1, 2013, available at http://www.ohchr.org/EN/NewsEvents/Pages/Display News.aspx?NewsID=13278\&LangID=E (decrying the force-feeding of the detainees as contrary to international law).

148. See Carol Rosenberg, Military imposes blackout on Guantánamo hunger-strike figures, miamiherald.com, Dec. 3, 2013, available at http://www.miamiherald.com/ 2013/12/03/3795285/guantanamo-ends-daily-hunger-strike.html (visited Feb. 26, 2014).

149. See President Barack Obama, Remarks by the President at the National Defense University (May 23, 2013), available at http://www.whitehouse.gov/the-pressoffice/2013/05/23/remarks-president-national-defense-university.

150. See President Barack Obama, Closure Of Guantanamo Detention Facilities (Jan. 22, 2009), available at http://www.whitehouse.gov/the_press_office/ClosureOf GuantanamoDetentionFacilities (visited Sept. 22, 2013).

151. See Boumediene v. Bush, 553 U.S. 723 (2008) (demanding improved procedural protections for detainees to comport with constitutional due process requirements); Hamdan v. Rumsfeld, 548 U.S. 557 (2006) (demanding congressional authorization for military commissions); Hamdi v. Rumsfeld, 542 U.S. 507, 538 (2004) (finding the lack of due process protections in the military commission system to be unconstitutional).

152. See Hamdi v. Rumsfeld, 542 U.S. 507, 538 (2004) (acknowledging "the possibility that the [due process] standards [the Supreme Court] ha[s] articulated could be met by an appropriately authorized and properly constituted military tribunal"); see also Boumediene v. Bush, 553 U.S. 723 (2008) (same).

153. See Hamdi, 542 U.S. at 538. 
gesting that military commissions were not necessary to try detainees, President Obama in 2009 revived the military commission system, ${ }^{154}$ citing the long history of their use and military necessity. ${ }^{155}$ A July 2009 protocol noted that detainees are entitled to the presumption of trial in an ordinary criminal court, but numerous objective and subjective factors could warrant a change in venue, including strength of interest, efficiency, and "other prosecution considerations" such as the available sentence and the ability to use certain evidence in a given forum. ${ }^{156}$

Under the Military Commissions Act of 2009, evidence from torture or cruel, inhuman or degrading interrogations is disallowed, the use of hearsay is limited, defendants are granted greater latitude in selecting their counsel, and protections against self-incrimination were instituted. ${ }^{157}$ Nonetheless, significant deviations exist among the military commissions, the courts-martial system, and ordinary criminal courts. Defendants in military commissions are guaranteed neither the right to remain silent or the right to the exclusion of their previous coerced statements, ${ }^{158}$ nor the right to a speedy trial. ${ }^{159}$ Trial for ex post facto crimes is permissible in a military commission. ${ }^{160}$ Guilty verdicts in non-capital cases can be rendered by twothirds of the jury. ${ }^{161}$ Hearsay evidence is more easily admissible and access to classified information is significantly curtailed. ${ }^{162}$ The controversial and problematic curtailing of these due process protections

154. See David E. Sanger, Obama After Bush: Leading by Second Thought, N.Y. Times, May 15, 2009, at A3 (discussing President Obama's changing stance on the utility of military commissions).

155. Press Release, The White House, Office of the Press Secretary, Statement of President Barack Obama on Military Commissions (May 15, 2009), http://www. whitehouse.gov/the_press_office/Statement-of-President-Barack-Obama-on-MilitaryCommissions/ (last visited Oct. 21, 2010).

156. See Department of Defense \& Department of Justice Protocol, Determination of Guantanamo Cases Referred for Prosecution, at I22 (July 20, 2009).

157. See Jennifer K. Elsea, Comparison of Rights in Military Commission Trials and Trials in Federal Criminal Court, Congressional Research Service, Feb. 28, 2013, available at $\mathrm{http} / / / \mathrm{www}$. fas.org/sgp/crs/natsec/R40932.pdf (offering a detailed comparison of the rights guaranteed under the Military Commissions Act of 2009 and those offered in ordinary criminal courts).

158. Compare Military Commissions Act $\S 949 \mathrm{a}(\mathrm{b})(2)(\mathrm{c})$ with Unif. Code of Military Justice, art. 31, §§ (a), (b), \& (d) (guaranteeing freedom from self-incrimination, and which are specifically made inapplicable to military commissions) and U.S. Const., amend. V (guaranteeing freedom from self-incrimination).

159. Military Commissions Act $§ 949 \mathrm{a}$. A speedy trial is guaranteed in both Article III courts and courts martial. U.S. Const., amend. VI (giving the right to a speedy trial); 18 U.S.C. $\$ 3161(\mathrm{~d})(2)$ (2008) (mandating commencement of trials within seventy days of indictment or original appearance in court). Unif. Code of Military Justice, art. 10.

160. Military Commissions Act $\S \S 948$ d, 950p. Cf. U.S. Const., art. 1, § 9, cl. 3 ("No ex post facto law shall be passed.").

161. Military Commissions Act $\S 949 \mathrm{~m}$. Cf. Fed. R. Crim. P. 31 (requiring unanimous jury verdicts for conviction).

162. Military Commissions Act $\S \S 949 a(b)(3)(D), 949 p-1-949 p-7$. 
is further compounded by the Obama administration's reservation of the right to continue to imprison anyone acquitted under the military commission system if security interests suggest that continued detention is necessary. ${ }^{163}$

A number of military commission trials have taken place at the Guantánamo Bay detention facility, ${ }^{164}$ despite critiques that the trials are both unnecessary given the availability of ordinary criminal courts and the courts-martial system and fundamentally unfair, and despite irregularities and setbacks. For example, Omar Khadr was first detained in 2002 at the age of fifteen, subjected to problematic interrogation, and eventually pled guilty to various terrorism-related charges. ${ }^{165}$ Salim Hamdan, a driver to Osama bin Laden, was convicted of conspiracy in a military commission, a charge that was overturned by an appellate court in 2012 based on the fact that conspiracy was not considered a war crime at the time that Hamdan was detained. ${ }^{166}$

\section{Torture and Accountability}

The United States has long been party to international treaties prohibiting torture as well as cruel, degrading, and inhuman treatment. Among them are the Universal Declaration of Human Rights, ${ }^{167}$ the Geneva Conventions, ${ }^{168}$ the International Covenant on Civil and Political Rights, ${ }^{169}$ the American Convention on Human Rights, ${ }^{170}$ and the Convention Against Torture. ${ }^{171}$ On the domestic level, the Fifth, Eighth and Fourteenth Amendments to the U.S. Con-

163. Jess Bravin, Detainees, Even if Acquitted, Might Not Go Free, Wall St. J. (July 8, 2009), http://online.wsj.com/article/SB124699680303307309.html (last visited September 21, 2013).

164. See Military Commissions Cases, Office of Military Commissions, available at http://www.mc.mil/CASES/MilitaryCommissions.aspx (visited Sept. 21, 2013).

165. See Charlie Savage, Deal Averts Trial in Disputed Guantánamo Case, nytimes.com, Oct. 25, 2010, available at http://www.nytimes.com/2010/10/26/us/26 gitmo.html (visited Sept. 21, 2013).

166. See Hamdan v. United States, 696 F.3d 1238 (D.C. Cir. 2012).

167. Universal Declaration of Human Rights, G.A. Res. 217A (III), U.N. Doc A/810, at 71 (Dec. 10, 1948).

168. Geneva Convention Relative to the Treatment of Prisoners of War, Aug. 12, 1949, 6 U.S.T. 3316, 75 U.N.T.S. 135 (entered into force Oct. 21, 1950); Geneva Convention Relative to the Protection of Civilian Persons in Time of War, Aug. 12, 1949, 6 U.S.T. 3516, 75 U.N.T.S. 287 (entered into force Oct. 21, 1950).

169. International Covenant on Civil and Political Rights, Dec. 16, 1966, 999 U.N.T.S. 171 (entered into force Mar. 23, 1976).

170. American Convention on Human Rights, O.A.S. Treaty Series No. 36, 1144 U.N.T.S. 123 (entered into force July 18, 1978), reprinted in Basic Documents Pertaining to Human Rights in the Inter-American System, OEA/Ser.L.V/II.82 doc. 6 rev. 1 at 25 (1992).

171. Convention Against Torture and Other Cruel, Inhuman or Degrading Treatment or Punishment, Dec. 10, 1984, 1465 U.N.T.S. 85 (entered into force June 26, 1987) ("Convention Against Torture"). 
stitution have been interpreted as prohibiting torture, ${ }^{172}$ and various domestic laws codify the obligations in the Convention Against Torture: the federal Torture Statute, ${ }^{173}$ the Torture Victim Protection Act of 1991, 174 the Alien Tort Claims Act, ${ }^{175}$ and the Foreign Affairs Reform and Restructuring Act of 1998. ${ }^{176}$

In late 2003, evidence surfaced of abuse and torture of detainees held at the Abu Ghraib prison in Iraq, at the hands of members of the U.S. military. ${ }^{177}$ Similar reports surfaced from the detention facility at Guantánamo Bay. ${ }^{178}$ Memos prepared by the Office of Legal Counsel in 2002 and 2003 advised the President and the military that detainees who were suspected members of Al Qaeda were not protected by international and domestic prohibitions against torture and, furthermore, that abuse of detainees would not constitute "torture" unless the interrogators intended to cause the type of pain associated with death or organ failure. ${ }^{179}$ Those memos were subsequently rescinded, and several members of the military were convicted at courts-martial for detainee abuse. ${ }^{180}$ Congress subsequently cemented the U.S. prohibition of the abuse and torture of detainees with the Detainee Treatment Act of 2005.181

In 2009, President Obama signed an executive order banning the use of enhanced interrogation techniques and limiting interrogation techniques to those permitted in the Army Field Manual. ${ }^{182}$ Such limitations were reinforced with the Military Commissions Act of 2009. ${ }^{183}$ Despite his campaign rhetoric on the need for a full account-

172. See generally Seth F. Kreimer, Too Close to the Rack and the Screw: Constitutional Constraints on Torture in the War on Terror, 6 U. PA. J. Const. L. 278 (2003).

173. Foreign Relations Authorization Act, Fiscal Years 1994 and 1995, Pub. L. No. 103-236, § 506, 108 Stat. 382 (codified at 18 U.S.C. $\$ \S 2340-2340 B(2006)$ ).

174. Torture Victim Protection Act of 1991, Pub. L. No. 102-256, 106 Stat. 73 (codified at 28 U.S.C. $\$ 1350$ note (2006)).

175. Alien Tort Claims Act, 28 U.S.C. $§ 1350$ (2006).

176. Foreign Affairs Reform and Restructuring Act of 1998, Pub. L. No. 105-277, $\S 2242($ a), 112 Stat. 2681 (codified at 8 U.S.C. $§ 1231$ (2006)).

177. Seymour M. Hersh, Torture at Abu Ghraib, The New Yorker (May 10, 2004) available at www.newyorker.com/archive/2004/05/10/040510fa_fact.

178. See, e.g., Ctr. for Constitutional Rights, Report on Torture and Cruel, Inhumane, and Degrading Treatment of Prisoners at Guantánamo Bay, Cuba (2006) available at http://ccrjustice.org/files/Report_ReportOnTorture.pdf.

179. Memorandum for Alberto R. Gonzales, Counsel to the President, from Jay S. Bybee, Asst. Atty. General, Standards of Conduct for Interrogation Under 18 U.S.C. $\S \S 2340-2340$ A (Aug. 1, 2002); Memorandum from Jay S. Bybee, Asst. Atty. General, regarding Standards of Conduct for Interrogation Under 18 U.S.C. $\$ \$ 2340-2340 A$ (Aug. 1, 2002).

180. Scott Shane, David Johnston and James Risen, Secret U.S. Endorsement of Severe Interrogation, N.Y. Times, Oct. 4, 2007, available at http://www.nytimes.com/ 2007/10/04/washington/04interrogate.html?pagewanted=all.

181. Detainee Treatment Act of 2005, Pub. L. No. 109-148 §§ 1001-06, 119 Stat. 2739 (codified at 42 U.S.C $\$ 2000$ dd (2006)).

182. Exec. Order No. 13,491, 74 Fed. Reg. 16,4893 (Jan. 22, 2009).

183. Military Commissions Act of 2009, Pub. L. No. 111-84, § 1802, 123 Stat. 2190, 2608 (codified at 10 U.S.C. $§ 950 t(11)$ ). 
ing of torture, President Obama has not pursued prosecution and has precluded a full investigation of those who created the policies that arguably allowed torture to occur. ${ }^{184}$

\section{Non-refoulement}

The non-refoulement obligation in Article 3 of the Convention Against Torture ${ }^{185}$ applies to U.S. extraordinary rendition practices and the movement of detainees from the Guantánamo detention facility. With regard to the former, when Canadian-Syrian dual citizen Maher Arar was rendered to Syria, the U.S. was obligated to seek assurances that he would not be mistreated there. However, evidence suggests that Arar was subjected to prolonged abuse and torture by his captors in Syria. ${ }^{186}$ With regard to Guantánamo, several detainees have been cleared for release, but under the obligation of nonrefoulement, the U.S. continues to hold them because of fear of torture upon return to their countries of citizenship. ${ }^{187}$

\section{B. Extra-Territorial Terrorism Law Enforcement}

Since the attacks of September 11, extraordinary rendition has been used to capture over 100 suspected terrorists in foreign countries and remove them to other nations for interrogation and control purposes. Some such detainees suffered extreme abuse and torture at the hands of their interrogators. ${ }^{188}$ Several have brought suits in U.S. courts seeking compensation for their treatment. Despite substantial evidence that citizens of Canada, ${ }^{189}$ Germany ${ }^{190}$ and the United Kingdom, ${ }^{191}$ among others, were rendered by the U. S. government to other nations and were subsequently abused by the

184. Scott Shane, No Charges Filed on Harsh Tactics Used by the C.I.A, nytimes. com, Aug. 30, 2012, available at http://www.nytimes.com/2012/08/31/us/holder-rulesout-prosecutions-in-cia-interrogations.html?pagewanted=all (visited Sept. 27, 2013).

185. Convention Against Torture, supra note 168, Art. 3.

186. See Human Rights Watch, Torture and Non-Refoulement, Jan. 29, 2004, available at http://www.hrw.org/news/2004/01/28/torture-and-non-refoulement (detailing Arar's situation).

187. International Committee of the Red Cross, Persons detained by the US in relation to armed conflict and counter-terrorism-the role of the ICRC, June 18, 2013 http://www.icrc.org/eng/resources/documents/misc/united-states-detention.htm.

188. See Amrit Singh, Globalizing Torture: CIA Secret Detention and Extraordinary Rendition, Open Society Foundations, at 13-15 (2013) (describing the history and use of extraordinary rendition).

189. See Commission of Inquiry into the Actions of Canadian Officials in Relation to Maher Arar, Report of the Events Relating to Maher Arar: Analysis and Recommendations (2006). See also Kent Roach, Review and Oversight of National Security Activities and Some Reflections on Canada's Arar Inquiry, 29 Cardozo L. Rev. 53 (2008).

190. See Jane Mayer, The Dark Side 282-87 (2008) (detailing Khalid El-Masri's plight).

191. See Sudha Setty, Judicial Formalism and the State Secrets Privilege, 38 Wм. Mitchell L. Rev. 1630, 1634-35 (2012) (detailing the claims of Binyam Mohamed). 
security forces in the nations to which they were rendered, all such suits have been dismissed on procedural bases. ${ }^{192}$

In 2009 the Obama administration created a task force to study the practice of extraordinary rendition with the aim of ensuring compliance with domestic and international human rights standards and legal norms. ${ }^{193}$ Renditions are believed to be continuing under this articulated standard. ${ }^{194}$

\section{Secrecy And Terrorism}

\section{A. Secrecy Claims and Secret Evidence}

The Classified Information Procedures Act (CIPA) is a 1980 law that established procedures for the use of classified and secret information in criminal trials. ${ }^{195}$ CIPA outlines a comprehensive set of procedures for the treatment of evidence in criminal cases that implicate classified information or rely on evidence that is classified. For example, CIPA allows the government, under limited circumstances, to substitute unclassified summaries of classified evidence. ${ }^{196}$ The Supreme Court in Boumediene $v$. Bush acknowledged the need to deal with classified information in a sensitive and thoughtful manner, and expressed confidence that ordinary criminal courts would be able to manage the task successfully. ${ }^{197}$

\section{B. Secrecy in the Courtroom and Anonymous Witnesses: Secret and Classified Evidence in Civil Suits}

The state secrets privilege is a common law evidentiary privilege that enables the government to prevent disclosure of sensitive state secrets in the course of litigation. The claim of privilege by the government, if upheld by a court, can result in consequences ranging from the denial of a discovery request for a particular document to the outright dismissal of a suit. Although a balancing test for assessing claims of privilege was established in the $1950 \mathrm{~s},{ }^{198}$ a meaningful assessment has often been precluded by the judicial tendency to uphold claims of privilege without engaging in a substantial analysis of

192. E.g., Mohamed v. Jeppesen Dataplan, Inc., 614 F.3d 1070, 1092-93 (9th Cir. 2010) (en banc); Arar v. Ashcroft, 585 F.3d 559, 565 (2d Cir. 2009), cert. denied, 130 S. Ct. 3409 (2010); El-Masri v. United States, 437 F. Supp. 2d 530 (E.D. Va. 2006), aff'd , 479 F.3d 296 (4th Cir. 2007), cert. denied, 128 S. Ct. 373 (2007).

193. See Executive Order 13,491, Ensuring Lawful Interrogations at § (5)(e)(ii) (Jan. 22, 2009).

194. See David Johnston, U.S. Says Rendition to Continue, But With More Oversight, nytimes.com, Aug. 24, 2009, available at http://www.nytimes.com/2009/08/25/ us/politics/25rendition.html?_r=0 (visited Sept. 22, 2013).

195. Classified Information Procedures Act of 1980, Pub. L. No. 96-456,94 Stat 2025.

196. Id. at 6 .

197. Boumediene v. Bush, 553 U.S. 723, 128 S. Ct. 2229, 2276 (2008).

198. United States v. Reynolds, 345 U.S. 1 (1953). 
the underlying evidence or of the government's claimed need for nondisclosure. ${ }^{199}$ In 2009, the Obama administration promised to reform the use of the state secrets privilege to allow for greater government accountability. ${ }^{200}$ However, the administration's continued aggressive use of the privilege, seeking and winning dismissal of suits alleging serious government abuse such as torture ${ }^{201}$ suggests only continuity in the use of the privilege to prevent meaningful accountability through civil suits.

\section{Conclusion: Assessment of U.S. Anti-Terrorism Laws}

In the last four years, U.S. counterterrorism policy has shifted in some significant ways, such as ending the use of abusive interrogation practices and accepting that international law applies to U.S. counterterrorism practices. However, the continuity between the Bush and Obama administrations in the substance of many counterterrorism programs, the assertion of high levels of presidential power and the continued high level of secrecy has created a bipartisan imprimatur of the robust counterterrorism programs that exist today, as well as the many problematic aspects of those programs. Congress, the judiciary and the public, all grateful that no large-scale terrorist attacks have occurred since 2001 and cognizant that threats still exist, have been largely acquiescent despite significant costs to human rights and civil liberties in the form of racial and religious profiling, indefinite detention, expansive and seemingly poorly controlled surveillance, extrajudicial killings, and torture and other abuses for which there has been a pronounced lack of accountability.

The government's aggressive counterterrorism stance has influenced actions and policies outside of the U.S. federal government: the work of domestic local and state-level law enforcement has been altered through federal programs mandating vertical informationsharing and coordination; the U.S. has exerted significant influence on the United Nations Security Council in shaping and promoting resolutions that have had a worldwide impact on counterterrorism programs; and the U.S. has exerted its soft power to attempt to influence other nations to shape their own counterterrorism policies in

199. See Setty, supra note 191.

200. See Memorandum from Eric Holder, Attorney Gen., on Policies and Procedures Governing Invocation of the State Secrets Privilege to Heads of Exec. Dep'ts \& Agencies (Sept. 23, 2009), available at http://legaltimes.typepad.com/files/ag-memore-state-secrets-dated-09-22-09.pdf (establishing layers of internal review within the Department of Justice and including a new executive branch policy to report to Congress any invocations of the state secrets privilege).

201. See Mohamed v. Jeppesen Dataplan, 614 F.3d 1070 (9th Cir. 2010) (en banc) (dismissing a suit seeking compensation for extraordinary rendition and torture based on the government's invocation of the state secrets privilege). 
ways that promote U.S. interests. ${ }^{202}$ Furthermore, the U.S. stance on issues like foreign surveillance and the use of drones for targeted killings in areas that are not active theaters of war has set a dangerous precedent with regard to other nations attempting to develop and use the same technology. ${ }^{203}$ It may be that the muscular stance of the U.S. on such issues will promote a similar response in other nations as their technology and power develops.

Future challenges for U.S. counterterrorism law are manifold. The driving imperative will continue to be recognizing and confronting continuing threats posed by al-Qaeda, other foreign terrorist groups, domestic terrorism and cyberterrorism. However, the U.S. would do well to improve its transparency and accountability mechanisms to comport with the rule of law and maintain democratic values. Such initiatives are unlikely to stem from the executive branch, which means that the judiciary, Congress, and the public must engage more fully to insist upon open debate, accountability and further oversight and constraint.

The U.S. response to terrorism has been multifaceted and expansive, reflective of the U.S. role in global security, and is an ongoing work in progress. Branches of the federal government and the public question and redefine their obligations and roles in upholding security while safeguarding the rule of law, and the debate over the appropriate course of action on these matters will no doubt continue for the foreseeable future.

202. See, e.g., Setty, supra note 191, at 1643-45, 1652-53.

203. See, e.g., Andrew Erickson and Austin Strange, China Has Drones. Now What?, foreignaffairs.com, May 23, 2013, available at http://www.foreignaffairs.com/ articles/139405/andrew-erickson-and-austin-strange/china-has-drones-now-what (raising questions as to how China will deploy its military drone capability). 